\title{
Legal Responsibilities and Restrictions on Veterinarians Working with Wildlife
}

\author{
REBECCA DUERr, DVM, MPVM \\ INTERNATIONAL BIRD RESCUE \\ FAIRFIELD, CA \\ Julia K. WhitTington, DVM \\ University of Illinois College of Veterinary Medicine \\ URBANA, IL
}

Keywords: Regulations, wildlife, veterinary, permits, Migratory Bird Treaty Act

\section{INTRODUCTION}

Veterinarians who treat wildlife in the United States (US) span a breadth of circumstances, from exclusively zoo and wildlife rehabilitation veterinarians to government or academic research veterinarians to veterinary medical teaching hospital faculty to private practitioners. It is likely that the last category, private practitioner, holds the largest number of veterinarians working with wildlife. Private practitioners who work with wildlife often treat animals for a particular rehabilitator as part of the rehabilitator's permitting requirement to have a relationship with a licensed veterinarian. Some practitioners do this work pro bono while others charge a fee for service, although many veterinarians offer steep discounts for treating a rehabilitator's wild patients. Some practitioners visit the wildlife facility to provide veterinary services; others see animals only when brought to their clinic. Some private practitioners are themselves wildlife rehabilitation permit-holders.

Regardless of circumstances, however, all veterinarians who wish to treat wildlife must be aware of the laws and regulations that govern this work, and also must understand the ethical obligations incurred when treating wild animals. Those with little experience with the rehabilitation of wildlife would be well

Rebecca Duerr, DVM, MPVM is the clinical veterinarian and research director at International Bird Rescue's two wildlife clinics in California. She completed her DVM, MPVM, and PhD degrees at University of California Davis.

Julia Wittington, DVM is a clinical associate professor, head of the companion exotic animal medicine service, and director of the Wildlife Medical Clinic at Illinois College of Veterinary Medicine. served to read the Wildlife Rehabilitator's Code of Ethics published in the Minimum Standards for Wildlife Rehabilitation (Miller 2012). This document elucidates many of the basic tenets of wildlife rehabilitation, including "Releasable animals should be maintained in a wild condition and released as soon as appropriate. Non-releasable animals which are inappropriate for education, foster-parenting, or captive breeding, have a right to euthanasia."

Although this article primarily discusses federal rules and regulations, caregivers also must be aware that state and local regulations apply. Some species require special permits or are protected by federal laws and regulations (migratory birds, threatened or endangered species). Some states do not allow or have special restrictions on the rehabilitation of certain animals, such as deer or rabies vector species (raccoons, skunks, bats, coyotes, others), may have special requirements for release locations, or may expressly prohibit the release of non-native species into the wild. Rules governing game birds and non-native species vary widely by state. Big game or extremely dangerous animals, such as deer, elk, antelope, moose, big horn sheep, bison, bears, and mountain lions, often have special rules at the state level that govern their possession. State regulations pertaining to wildlife often are available through the individual state's agency responsible for wildlife management. The United States Fish and Wildlife Service (USFWS) maintains a listing of regulatory agencies for each state (www.fsw. gov/offices/statelinks.html). All applicable regulations must be understood by veterinarians and rehabilitators, especially prior to performance of medical procedures that may result in an animal that is unable to be released into the wild. Finding permanent placement for non-releasable wildlife is often difficult even for 
uncommon species. It is advisable to have placement identified prior to investing resources in surgical procedures if an animal is likely to be non-releasable. Euthanasia must be considered for any wild animal expected to be non-releasable following rehabilitation, and this includes animals deemed non-releasable due to behavioral issues.

Historically, many important laws and treaties have been adopted in the US with the intent of protecting native wildlife and their habitats. These policies collectively represent the nation's commitment to conservation initiatives. Each law and treaty has a unique purpose and may be found within the United States Code (USC) and the Code of Federal Regulations (CFR). The USC contains a consolidated and codified listing of all general and permanent US laws, passed by Congress, arranged by subject, and alphabetized in 51 title headings. The CFR is a compilation of general and permanent rules defining implementation of the laws as set forth by the executive departments and agencies of the federal government. The CFR is divided into 50 titles that represent subjects pertaining to federal regulation and each title is divided further into chapters that bear the names of the responsible government agency. Some title numbers are the same between USC and CFR, some are not. Laws pertaining to wildlife may be found in both the USC and the CFR, each with its own reference chapter listing (Endangered Species Act, 16 USC \$1531-1544, 50 CFR Part 17).

Management of wildlife is regulated by five federal agencies, all enforced by the US Department of Justice (Figure 1). Each agency has its own edict and focus making knowledge of these agencies and their regulations extremely valuable for the wildlife veterinarian and rehabilitator. These five agencies are the US Department of Interior (USDI) that houses the US Fish and Wildlife Service (USFWS), the US Department of Agriculture (USDA), the US Department of the Treasury that manages the Customs Service, the Department of Commerce (USDC) that houses the National Marine Fisheries Service (NMFS), and the Department of Health and Human Services (DHHS).

\section{US DEPARTMENT OF THE INTERIOR}

The USDI is the primary regulatory agency in the US responsible for providing oversight of conservation and management of natural resources. Created in 1849, the USDI oversees public lands, national parks, national wildlife refuges, mineral resources, and western water resources. Among its edicts is to uphold the Federal trust responsibilities to Native American

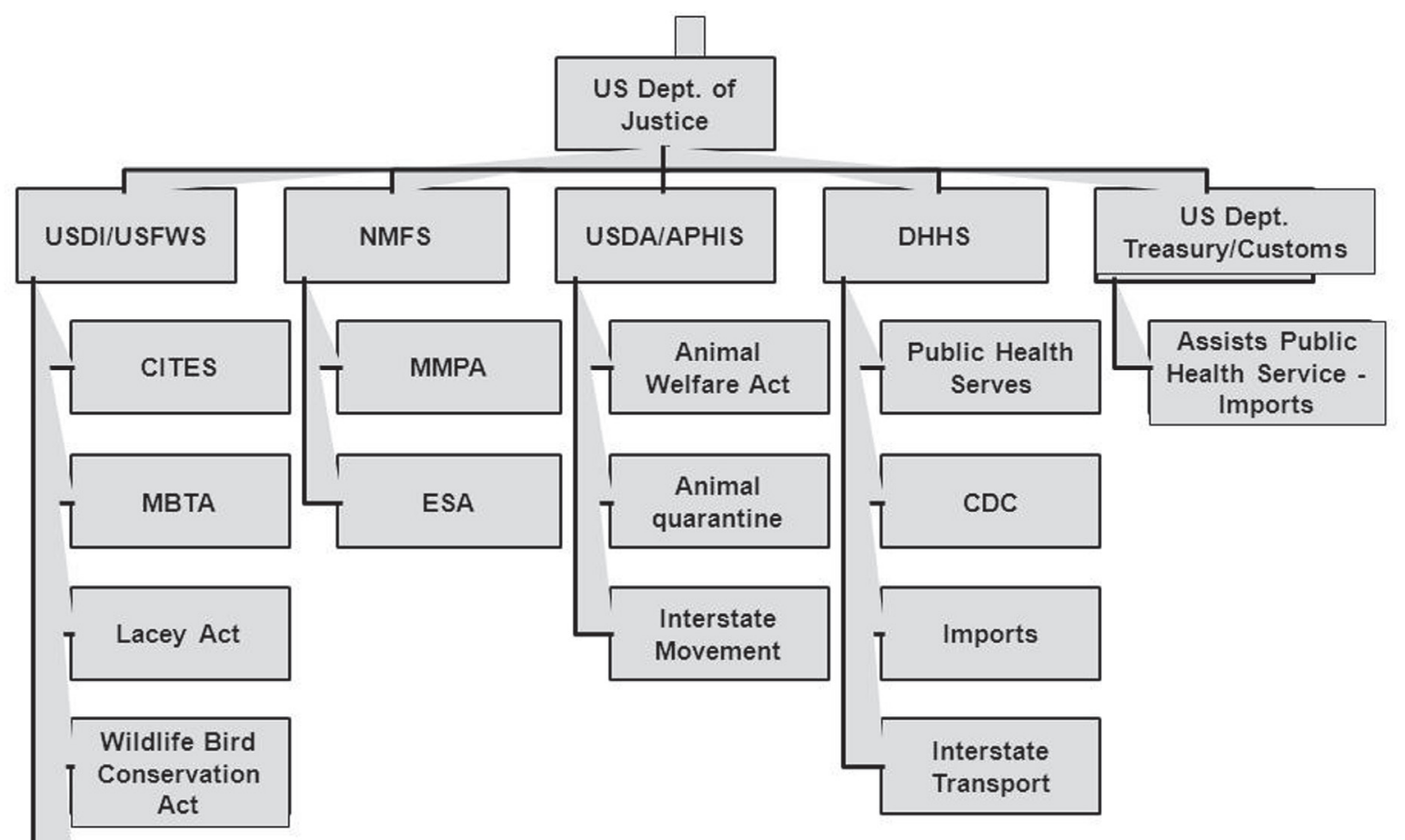

Figure 1. Federal wildlife agency organizational chart. 
tribes and Alaskan natives, as well as to provide historic preservation of native cultures. Migratory wildlife and endangered species conservation, surface-mined lands protection and restoration, and mapping of land and water use are also responsibilities of the USDI. The USDI is subdivided into four offices to provide appropriate oversight of its varied mission. The Office of Water and Science oversees the US Geological Survey and the Bureau of Reclamation. The Office of Land and Minerals Management oversees the Bureau of Land Management, the Office of Surface Mining Reclamation and Enforcement, and the three agencies of the reorganized Minerals Management Service, now The Bureau of Ocean Energy Management, The Bureau of Safety and Environmental Enforcement, and the Office of Natural Resources Revenue. The Office of Indian Affairs oversees the Bureau of Indian Affairs and the Bureau of Indian Education. The Office of Fish and Wildlife and Parks oversees the National Park Service and the US Fish and Wildlife Service.

\section{US FISH AND WILDLIFE SERVICE (USFWS)}

The USFWS was created in 1940 and moved under the regulatory umbrella of the USDI after a reorganization that combined the Bureau of Fisheries from the Department of Commerce with the Bureau of Biological Survey from the Department of Agriculture. The newly formed USFWS was given the responsibility of conserving and protecting fish, wildlife, and plants as well as their habitats. The USFWS administers the Endangered Species Act and enforces federal wildlife laws including the Marine Mammal Protection Act (MMPA), the Migratory Bird Treaty Act (MBTA), the Lacey Act, and the Wild Bird Conservation Act. International treaties such as the Convention on International Trade in Endangered Species of Wild Fauna and Flora (CITES) are also enforced by the USFWS. Title 16 (Conservation) of the USC contains most of the laws pertaining to wildlife that are enforced by the USFWS and Title 50 of the CFR outlines the regulations for implementation. Permits issued by the USFWS allow the permit holder to engage in specific activities working with wildlife and allows the Service to use the permits as a conservation tool to track activities potentially impacting wildlife populations. General regulations regarding permits and permit applications are found in Title 50 CFR Part 13. Specific programs of the USFWS include the migratory bird resource program responsible for protection of lands used by migratory birds, enforcement of laws pertaining to these populations, and oversight of population management including game harvesting. Other programs provide for the protection and population management of mammals, non-migratory birds, and fish including the Great Lakes fisheries. The USFWS is charged with providing national and international leadership in identifying, protecting, and restoring endangered species of fish, wildlife and plants. A summary of laws, treaties, and regulations administrated by the USFWS is available on the USFWS website http://www.fws.gov/permits/ ltr/ltr.html.

\section{Endangered Species Act (ESA): 16 USC \$1531-1544, Title 50 CFR Part 17. The ESA,} passed by Congress in 1973, is a written recognition by the United States government that various species of plants and animals have become extinct as a direct extension of economic growth and expansion that lacked adequate concern for conservation. The stated purpose of the ESA is to provide the means to conserve threatened and endangered species in the United States, and for the preservation of ecosystems which support these species, while working to achieve the goals of international programs with which the United States has formed treaties. The ESA is administered by the USFWS and the National Marine Fisheries Service (NMFS), with the USFWS having primary responsibility for freshwater and terrestrial species and NMFS being responsible for marine species. Species listed under the ESA may be either endangered or threatened and are considered for listing based on the condition of its habitat, overutilization of the species, pressure from disease or predation, adequacy of existing protection, and anthropogenic or natural pressures on the species impacting the likelihood of its future survival. If any one factor imperils a species' ability to survive, the USFWS is charged with taking measures to protect it.

The ESA prohibits the taking or transportation (interstate and international) of listed plants and animals (Title 50 CFR Part 17.11), or their parts and products, except as allowed for by federal permit. In the broadest sense of the word, the ESA defines the take of a species as "to harass, harm, pursue, hunt, shoot, wound, kill, trap, capture, or collect or attempt to engage in any such conduct." The word harm is defined as "an act which actually kills or injures wildlife" including habitat modification resulting in a species' inability to demonstrate essential behaviors such as breeding, eating, and finding shelter. The ultimate goal of the ESA is to remove listed endangered or threatened species from the list and that is accomplished through the implementation of recovery plans working with other federal agencies, states, 
and landowners. The ESA is the law which provides for United States participation in the Convention on International Trade in Endangered Species of Wildlife Fauna and Flora. Current species protected under the ESA may be found at the webpage of the Endangered Species Program, at <http://www.fws. gov/endangered/>.

Exceptions to the Endangered Species Act allow for specific circumstances where an individual or institution may work with an endangered species without an endangered species permit. This includes wildlife rehabilitators working under a valid migratory bird rehabilitation permit provided the permit holder notifies their regional Migratory Bird Permit Office immediately upon receipt of the bird.

\section{Convention on International Trade in Endangered Species of Wildlife Fauna and Flora (CITES). Title 50 CFR Part 23-CITES is} an agreement originally established in 1975 among 175 nations, designed to prevent the endangerment or extinction of species due to international trade. Species listed in one of three CITES appendices may not be imported or exported except as allowed by permit. CITES partners recognize that conservation of native species is a homeland initiative but that international cooperation is essential for prevention of species exploitation through international trade. Species listed on CITES Appendix I are those that are in imminent threat of extinction if international trade is not limited. CITES Appendix II includes species that are not presently threatened or endangered but that may become so if trade is not limited. Species that are not threatened but that could be mistaken for those that are because of similar appearance are also listed in Appendix II. Countries wishing to obtain cooperation in controlling international trade of certain species may list them in CITES Appendix III. The USFWS is the United States agency tasked with enforcing CITES which prohibits any person from importing, exporting, or engaging in international trade of any species, or specimen of a species, listed in the three appendices. CITES does not impose restrictions on transportation between the states or US territories. The CITES species database found on the CITES website <http://www.cites.org/eng/ resources/species.html> provides a current listing of all species regulated by each country. Restrictions also may apply to importation or exportation of biologic specimens from listed species, including blood, tissue, or other materials.

Title 50 CFR Part 14 provides further regulations pertaining to the importation, exportation, and transportation of wildlife. It is unlawful to import or export any wildlife except at a designated Customs port. Special permits may be issued from the USFWS to authorize importation or exportation of wildlife for scientific purposes but require an application that includes the purpose for the activities, the species and number of animals to be moved, and the location of acquisition. Specific criteria regarding enclosures, conveyance, food, water, handling, and care in transit are defined and must be adhered to when transporting wildlife under these regulations.

\section{Lacey Act: 16 USC 3371-3378, 18 USC} $\$ 42-43$, Title 50 CFR Part 16. The Lacey Act was enacted into law in 1900 and was the first broad-reaching law defining the collection and use of wildlife. Named for the bill sponsor, US Representative John Fletcher Lacey, the Lacey Act gave support to states in their efforts to prevent the illegal harvesting and interstate transport of wildlife. The Lacey Act prohibits the sale, acquisition, and interstate or international transport of any fish, wildlife, or plants, including their parts and products, that are indigenous to the United States or covered by CITES and that were obtained in violation of any law, treaty, or regulation of the United States or in violation of any Indian tribal law. Numerous amendments have expanded the scope of the Lacey Act to include provisions regarding injurious wildlife and captive wildlife safety.

The Lacey Act Amendments of 1981, also known as the Injurious Wildlife Act, states that no species of wildlife deemed potentially injurious to human beings, to the interests of agriculture, horticulture, forestry, or to wildlife or the wildlife resources of the United States may be imported into the United States or transported between states. Animals are deemed 'wild' if they are normally found in a wild state, regardless of captive rearing or breeding. Mammalian species considered injurious include 'flying foxes' or fruit bats (Pteropus spp.), any species of mongoose or meerkat, any species of European rabbit (Oryctolagus sp.), any species of wild dog (Cuon sp.), any species of multimammate rat or mouse (Mastomys spp.), the raccoon dog (Nyctereutes procyonoides), and the brushtail possum (Trichosurus vulpecula). Bird species considered injurious include the pink starling (Sturnus roseus), dioch species (Quelea quelea), Java sparrow (Padda oryzivora), and red-whiskered bul-bul (Pycnonotus jocosus). Zebra mussels (Dreissena polymorpha), Asian carp species, and snakehead species comprise the majority of injurious aquatic species and the brown tree snake (Boiga irregularis) is the sole reptile species listed. A list of species considered as injurious wildlife under the Lacey Act can be found on the USFWS website <http:// www.fws.gov/fisheries/ans/Current_Listed_IW.pdf $>$. 
Certain exceptions to the Injurious Wildlife Act may be made in order to import potential injurious animals for zoological, educational, medical, and scientific purposes providing appropriate precautions have been made to prevent accidental introduction. All other species of wild mammals, game and non-game birds, amphibians, and reptiles may be imported, transported, and possessed in captivity, without a permit, for scientific, medical, educational, exhibition, or propagating purposes, but shall not be released into the wild except by the state agencies having jurisdiction over the region's wildlife conservation. Exceptions to these regulations include eagles and migratory birds which are regulated by the Migratory Bird Act and psittacine birds whose importation and transport are governed by the US Public Health Service (42 CFR Parts 71-72).

In addition to making provisions regarding the movement of injurious wildlife, the Lacey Act serves to provide protection to captive animals by stipulating that wildlife being transported to the United States and US territories are kept under humane and healthful conditions. It also makes it illegal to cause physical disruption to the functioning of an animal enterprise or to cause property damages, including causing harm to animals. Animal enterprises are defined as commercial or academic institutions using animals for production or research, zoos, aquariums, circuses, rodeos, competitive events, fairs, or any event intended to advance agricultural arts and sciences.

A 2003 amendment to the Lacey Act, called the Captive Wildlife Safety Act, prohibits the transportation of big cats, including lions, tigers, leopards, snow leopards, clouded leopards, jaguars, cheetahs, and cougars, across state lines or the US border. Persons exempt from this law include those licensed by the USDA APHIS as stipulated by the Animal Welfare Act. Importation into or exportation out of the United States is also prohibited.

\section{Marine Mammal Protection Act: 16 USC 1361-1407, Title 50 CFR Part 18. The Marine} Mammal Protection Act was passed in 1972 in order to prevent marine mammal populations from falling to non-sustainable levels by restricting their harvesting, possession, transportation, sale, and importation. This statute applies to all marine mammals, and their products, with the exception of fur seals. Marine mammals under the jurisdiction of USFWS include sea and marine otters, manatees, walruses, and polar bears. Management of other marine mammal species is by the Office of Protected Resources of NMFS. Those wishing to rehabilitate marine mammals must obtain a Letter of Authorization (LOA) from USFWS or NMFS.

Fur Seal Act: 16 USC 1151-1153, Title 50

CFR Part 216. The Fur Seal Act provides management of the northern fur seal (Callorhinus ursinus), including regulating subsistence take in the Pribilof Islands by native Alaskans, and regulation of permits to possess and display fur seals.

\section{Wild Bird Conservation Act: 16 USC 4901-4916, Title 50 CFR Part 15. Congress} passed the Wild Bird Conservation Act in 1992 to establish regulations to limit or prohibit importation of exotic bird species by the United States, to assist in wild bird conservation and management programs in countries native to exotic birds, and to establish the Exotic Bird Conservation Fund. This Act was created in acknowledgment that the United States was the largest importer of exotic birds, contributing to significant decline in wild bird species, despite being a partner in CITES. All species listed in any Appendix to CITES are prohibited from being imported into the United States, with few exceptions. Those species not listed by CITES may also be banned if the country of origin has not provided for the conservation management of the species or demonstrated humane treatment of exotic birds during capture, transport, and maintenance. Import permits are required and issued for importation of exotic birds if the importation is not detrimental to the survival of the species and the bird is being imported for scientific research, zoological breeding or display, or as a personally owned pet of a US citizen returning to the country. The Exotic Bird Conservation Fund is funded by private and government sources, as well as from penalties and fines collected under the Wild Bird Conservation Act. The fund is used to provide financial and technical assistance for projects to conserve exotic birds in their native countries.

\section{Migratory Bird Treaty Act: 16 USC 703-} 712, Title 50 CFR Part 21. The early 1900 s was a time of appreciation for wild bird fauna, both as fashion accoutrements by high society and as a national treasure by game hunters and conservationists. In 1916, an international convention between the United States and Great Britain established a treaty to protect birds migrating between the US and Canada. This treaty became the foundation for the Migratory Bird Treaty Act which became law in 1918. Since then, the Act has been amended to incorporate treaties between the United States and Mexico (1936), Japan (1972), 
and the Union of Soviet Socialist Republics (1976). The Migratory Bird Treaty Act provides for the protection of all bird species, or family of birds, native to the United States or its territories that live, reproduce, or migrate within or across international borders during their annual life cycle. Non-native migratory birds, found in the US as a result of their intentional or unintentional introduction, are exempt from the Act.

The Migratory Bird Treaty Act makes it illegal to pursue, hunt, take, possess, import, export, transport, sell or offer to sell, purchase or offer to purchase, barter or offer to barter any migratory bird, migratory bird parts, migratory bird eggs, or nest without a valid permit. The Act does provide for the hunting of game birds and regulations regarding hunting of migratory game birds and crows are addressed in Title 50 CFR Part 20. Alaska subsistence harvesting of migratory birds is regulated by Title 50 CFR Part 92 . The Act also makes allowances for the removal of migratory birds that are causing harm to crops, plants, or fish in Title 50 CRF Parts 21.41-21.46. Over 800 species of birds enjoy protection from the Migratory Bird Treaty Act and a complete listing of species can be found in Title 50 CFR Part 10.13.

Permits are required, under this law, to work with migratory birds however certain exceptions exist

Table 1. General exceptions to the Migratory Bird Treaty Act.

The following persons, in the circumstances defined, may engage in activities pertaining to migratory bird species without possessing a migratory bird permit.

\begin{tabular}{|c|c|}
\hline 1 & Employees of the Department of the Interior - When performing official duties. \\
\hline 2 & $\begin{array}{l}\text { State game departments, municipal game farms/parks, public museums, zoological parks, public scientific } \\
\text { or educational institutions - Must be acquired by authorized person or by permit, must keep complete } \\
\text { records for } 5 \text { years. }\end{array}$ \\
\hline 3 & $\begin{array}{l}\text { Employees of federal, state, and local wildlife, land management, and public health agencies - May work } \\
\text { with dead or sick birds when infectious disease or natural toxin is suspected. }\end{array}$ \\
\hline \multirow[t]{4}{*}{4} & $\begin{array}{l}\text { Licensed veterinarians who are not rehabilitation permit holders- May temporarily possess, stabilize, or } \\
\text { euthanize sick and injured migratory birds, but must transfer bird to federally permitted rehabilitator with- } \\
\text { in } 24 \text { hours after stabilization (if permitted rehabilitator is not found, the veterinarian must contact the } \\
\text { Regional Migratory Bird Permit Office to obtain authorization to continue to possess the bird). }\end{array}$ \\
\hline & $\begin{array}{l}\text { Must contact local USFWS Ecological Services Office (http://offices.fws.gov) immediately upon receiving a } \\
\text { threatened or endangered migratory bird species. }\end{array}$ \\
\hline & $\begin{array}{l}\text { May euthanize and dispose of migratory birds in accordance with the code for Rehabilitation permits } \\
\text { (Title } 50 \text { CFR Part 21.31). }\end{array}$ \\
\hline & $\begin{array}{l}\text { Must keep records of all migratory birds that die or are euthanized while under care, records to } \\
\text { include species, injury, date of acquisition, date of death, cause of death. }\end{array}$ \\
\hline \multirow[t]{9}{*}{5} & Public Citizens - Under certain conditions \\
\hline & $\begin{array}{l}\text { To humanely remove trapped migratory birds, including endangered species, from the interior of a } \\
\text { structure if the bird is posing a health threat, is attacking humans or posing a threat to human safety } \\
\text { because of its activities, poses a threat to commercial interests, or may become injured itself. }\end{array}$ \\
\hline & $\begin{array}{l}\text { Humane methods of capture must be used, adhesive traps are prohibited. Use of falconry birds to } \\
\text { remove the trapped bird is prohibited. Causing the death of a trapped bird or using techniques likely } \\
\text { to cause death is prohibited. }\end{array}$ \\
\hline & If death occurs, the carcass must be disposed of immediately. \\
\hline & $\begin{array}{l}\text { The bird must be immediately released into a suitable habitat unless it is exhausted, ill, injured, or } \\
\text { orphaned }\end{array}$ \\
\hline & $\begin{array}{l}\text { If the bird is not releasable for the reasons stated above, the property owner must contact a federally } \\
\text { permitted rehabilitator }\end{array}$ \\
\hline & Bald or golden eagles may not be removed without a permit. \\
\hline & $\begin{array}{l}\text { A federally permitted migratory bird rehabilitator must assist in the removal of an active nest with } \\
\text { eggs or nestlings. }\end{array}$ \\
\hline & All actions must comply with state and local regulations and ordinances. \\
\hline
\end{tabular}


for specific individuals or institutions in particular circumstances (Table 1).

Waterfowl-Migratory bird permits are not required for captive-reared mallard ducks. However, all mallard ducks in captivity without a permit are required to be permanently 'marked', by means of toe amputation, wing pinioning, banding or tattooing, prior to reaching six weeks of age. Other species of captive migratory waterfowl may be maintained in captivity without a migratory bird permit if they were obtained from a licensed breeder. Special Canada goose permits may be issued by the USFWS to a state wildlife agency authorizing control and management activities of certain resident Canada goose populations that would otherwise be prohibited by the Migratory Bird Treaty Act.

Banding-A specific banding permit is required under the Migratory Bird Treaty Act to band a migratory bird. This regulation is overseen by the Bird Banding Laboratory in Laurel Maryland. Applications for banding permits must be submitted to the Laboratory for consideration. Only official USFWS bands may be used to mark migratory birds; other bands, clips, dye, or other methods of marking are prohibited without specific authorization. In general, banding permits are not issued for rehabilitation purposes although rehabilitators may become sub-permit holders under a permit holder that was issued a banding permit for research purposes.

Falconry-Falconry standards and permitting are defined in Title 50 CFR Part 21.29. The Migratory Bird Treaty Act prohibits the taking, ownership, and use of any raptor, including Falconiformes (vultures, kites, eagles, hawks, caracaras, falcons), and Strigiformes (owls) without issuance of a federal permit. States, tribes, and territories of the United States that wish to allow falconry practices are required to establish laws regulating falconry activities that meet the standards set forth by the Migratory Bird Treaty Act. Falconers are classified by their level of experience: Apprentice, General, and Master. Activities allowable by law under the Migratory Bird Treaty Act vary between these classifications (Table 2).

Certain raptors used in falconry practices must be banded using a permanent, non-reusable, numbered USFWS band issued by the governing state. Goshawks, Harris's hawks, peregrine falcons, and gyrfalcons removed from the wild must be banded. Captive bred raptors must also be banded with a seamless breeder band which, if lost, must be replaced with a USFWS issued band. Breeder bands should not be used on raptors removed from the wild. Lost bands must be reported within 5 days. Falconers removing raptors from the wild must report the acquisition within 10 days to the USFWS either by entering the data, including band number, into an electronic database (http://permits.fws.gov/186A) or by filing appropriate documents with their governing state. No more than two raptors may be taken from the wild each year by any given falconer and any bird captured unintentionally must be released immediately. If the falconer is lawfully collecting a nestling bird, they must leave at least one other nestling in the nest. Falconers are required to carry their permits whenever they are engaged in falconry activities and may transport legally owned birds across state borders.

All raptors held under falconry permits must be maintained in humane and healthful conditions including protection from adverse environmental conditions, predators, and domestic animals. Facilities

Table 2. Classifications and restrictions for falconry permits and activities.

\begin{tabular}{|c|c|c|c|}
\hline & APPRENTICE & GENERAL & MASTER \\
\hline Age restrictions & $>12$ years of age & $>16$ years of age & - \\
\hline Experience & $\begin{array}{l}\text { None-must have let- } \\
\text { ter of commitment to } \\
\text { mentor from General or } \\
\text { Master Falconer (> } 18 \\
\text { years of age, with }>2 \\
\text { years of experience) }\end{array}$ & $\begin{array}{l}>2 \text { years of experience } \\
\text { as Apprentice Falconer }\end{array}$ & $\begin{array}{l}>5 \text { years of experience } \\
\text { as General Falconer }\end{array}$ \\
\hline Number of birds & 1 & $\leq 3$ & $\leq 5$ \\
\hline Age of bird & $<1$ year, no nestlings & Any & Any \\
\hline Species allowed & $\begin{array}{l}\text { No federally listed } \\
\text { endangered or threat- } \\
\text { ened spp., no eagles, no } \\
\text { human imprints }\end{array}$ & $\begin{array}{l}\text { Any legally allowed, no } \\
\text { eagles }\end{array}$ & $\begin{array}{l}\text { Any legally allowed, } \\
\text { eagles (except bald } \\
\text { eagle), any captive bred } \\
\text { raptors }\end{array}$ \\
\hline
\end{tabular}


housing raptors must have at least one perch per bird and access to sunlight. Untethered birds should have an area large enough to allow flight, while tethered birds should be allowed to fully extend their wings without damage. If a raptor is injured during capture by a falconer, the falconer is responsible for the cost of providing appropriate care and rehabilitation for the bird. The injured bird should be treated by a veterinarian or a permitted wildlife rehabilitator, or given to an agent of the appropriate wildlife agency. The falconer may choose to place the bird on their falconry permit but the bird will count against their possession limit. Falconers may also accept raptors of any age from wildlife rehabilitators if the falconer is permitted to have that particular species. Transfer of the bird is at the discretion of the rehabilitator and the transferred bird will count against the falconer's legal limit of birds they may take from the wild that year. General and Master falconers may assist a permitted wildlife rehabilitator in reconditioning a wild raptor and may keep the bird in their facilities without the bird counting against their allowable limits. The rehabilitator should provide the falconer with a letter identifying the bird and explaining the role of the falconer in the bird's care. If the raptor is subsequently non-releasable, the falconer must return the bird within the 180 days that the wildlife rehabilitator is allowed to possess the bird. Special permission must be obtained to keep the raptor longer than this time-frame. Alternatively, the bird can be transferred to the falconer's permit for the remainder of its captivity.

A raptor that has been maintained on a permit as a falconry bird may be released into the wild as long as its release is in accordance with all federal, state, and local laws. Only species native to the area may be released and the release must be at the appropriate time of year and location for the species. Prior to release, the bird's falconry band should be removed and the release must be reported within 10 days in the electronic falconry database. Hybrid birds may not be released into the wild population and captive bred birds require special permission. Raptors maintained under a falconry permit may be transferred to another type of permit if an injury occurs that prevents the use of the bird in falconry activities. The need for transfer must be certified by a veterinarian or permitted wildlife rehabilitator. Wild caught raptors that have been used as falconry birds for at least two years may be transferred to a raptor propagation program. Wild caught raptors may not be sold. Falconry birds may be used for education programs by General or Master level falconers as long as the topic is falconry or conservation and the falconer assumes legal responsibility for the program activities.
Rehabilitation-A rehabilitation permit is necessary to take, possess, or transport a migratory bird legally for rehabilitation purposes, with the notable exceptions listed in Table 1. The rehabilitation permit regulations are found in Title 50 CFR Part 21.31 and stipulate that rehabilitators may provide rehabilitative care for migratory birds for up to 180 days and may transport the birds to a suitable habitat for release. Legally permitted rehabilitators are authorized to transfer, release, or euthanize migratory birds and may dispose of carcasses. Additionally, migratory birds brought to a wildlife rehabilitator may be received, stabilized, and transferred within 48 hours even if the individual is not permitted to rehabilitate that species. The rehabilitation permit does not authorize the permit holder to use migratory birds for education purposes. Persons applying for a migratory bird rehabilitation permit will need to provide a copy of their state rehabilitation permit, if one is required. Permit applicants must be at least 18 years of age with over 100 hours of practical experience obtained over a year's time working with the species they intend to rehabilitate. Additionally, the applicant will need to demonstrate the presence or access to appropriate facilities and must either be or have a working relationship with a licensed veterinarian. Any individual performing activities on a regular basis under a rehabilitator's permit, including transporting migratory birds, should be listed as a subpermittee. The subpermittee must be at least 18 years of age and the permit holder is responsible for ensuring that the subpermittee, as well as other staff, are following the rules dictated by the permit. A summary of regulations pertaining to rehabilitation activities under the Migratory Bird Treaty Act are listed in Table 3.

Migratory birds kept as educational animals are regulated by Title 50 CFR Part 21.27. As per this regulation, birds kept under a Special Purpose Possession (Educational Use-Live Specimens) permit remain the property of the USFWS. Prior written approval from the USFWS is required to obtain, transfer, or dispose of any migratory bird for educational purposes and all birds must be captive-bred or deemed non-releasable. Facilities housing migratory raptors under a Special Purposes Education permit must be adequate for the species and will be evaluated using the guidelines established in Care and Management of Captive Raptors by the Raptor Center, University of Minnesota. Acknowledgement that covered birds are being maintained with express permission of the USFWS must be stated, verbally or in writing, whenever birds are exhibited under this permit. Permit holders are required to carry a copy of their permit when engaged 
Table 3. Selected regulations pertaining to migratory bird rehabilitation activities.

\section{GUIDELINES SET FORTH IN MINIMUM STANDARDS FOR WILDLIFE REHABILITATION (Miller 2012)}

\begin{tabular}{|c|c|}
\hline \multirow[t]{6}{*}{ Facilities } & $\begin{array}{l}\text { Secure, providing protection from predators, weather, domestic animals, and human } \\
\text { disturbances }\end{array}$ \\
\hline & Safe cage materials \\
\hline & Clean, well-ventilated \\
\hline & Appropriate number of birds, perches, enrichments \\
\hline & Group housing for compatible species only \\
\hline & No public display \\
\hline Diet & Diet must be appropriate and complete for species/individual \\
\hline \multirow[t]{10}{*}{ Disposition } & Releasable birds must be released to suitable habitat as soon as seasonably appropriate \\
\hline & Release must be within 180 days \\
\hline & $\begin{array}{l}\text { Captive care }>180 \text { days requires approval from USFWS Regional Migratory Bird Permit } \\
\text { Office }\end{array}$ \\
\hline & Every precaution to avoid imprinting or habituation must be taken \\
\hline & Imprinted birds will be transferred as directed by USFWS \\
\hline & Euthanasia is indicated for migratory birds with the following conditions: \\
\hline & $\begin{array}{l}\text { Inability to self-feed, perch upright, or ambulate without injury that medical or rehabili- } \\
\text { tative care will not correct }\end{array}$ \\
\hline & Blindness \\
\hline & Requires amputation of a leg, foot, or wing at the elbow or above \\
\hline & $\begin{array}{l}\text { Exceptions to the above require a written testament from a licensed veterinarian who } \\
\text { agrees to provide life-long veterinary care for the bird, an appropriate placement for the } \\
\text { bird with a person authorized to possess it, and approval from the USFWS }\end{array}$ \\
\hline \multirow[t]{6}{*}{ Endangered Species } & $\begin{array}{l}\text { USFWS notification required within } 24 \text { hours of receiving live or dead threatened or endan- } \\
\text { gered species, bald eagle, or golden eagle. }\end{array}$ \\
\hline & Release of endangered or threatened species is subject to specific USFWS requirements \\
\hline & $\begin{array}{l}\text { Authorization from USFWS Regional Migratory Bird Permit Office required prior to euthana- } \\
\text { sia of endangered or threatened migratory bird species }\end{array}$ \\
\hline & $\begin{array}{l}\text { Euthanasia may be performed without prior approval when Office personnel are } \\
\text { unavailable and prompt euthanasia is warranted to provide humane care }\end{array}$ \\
\hline & $\begin{array}{l}\text { Approval necessary prior to disposal or transfer of any live or dead threatened or endan- } \\
\text { gered migratory bird or their parts and feathers }\end{array}$ \\
\hline & $\begin{array}{l}\text { Approval is necessary prior to performing a necropsy on a threatened or endangered migra- } \\
\text { tory bird }\end{array}$ \\
\hline \multirow[t]{4}{*}{ Placement } & $\begin{array}{l}\text { Non-releasable birds suitable for educational programs, research projects, or other autho- } \\
\text { rized activities may be placed }\end{array}$ \\
\hline & Requires prior approval from USFWS Regional Migratory Bird Permit Office \\
\hline & Requires that recipient possesses the appropriate permits \\
\hline & With approval, non-releasable birds may be held $>180$ days for fostering purposes \\
\hline Eagles & $\begin{array}{l}\text { All dead bald and golden eagles, and their parts and feathers, should be sent to the } \\
\text { National Eagle Repository }\end{array}$ \\
\hline \multirow[t]{2}{*}{$\begin{array}{l}\text { Disposal of carcasses } \\
\text { and tissue }\end{array}$} & $\begin{array}{l}\text { Disposal of carcasses must be prompt and in a manner that prevents exposure to wild } \\
\text { populations }\end{array}$ \\
\hline & A reasonable number of feathers may be maintained for imping purposes \\
\hline $\begin{array}{l}\text { Disposal of carcasses } \\
\text { and tissue }\end{array}$ & Necropsies may be performed \\
\hline
\end{tabular}


Table 3 (continued). Selected regulations pertaining to migratory bird rehabilitation activities.

\begin{tabular}{|c|c|}
\hline & $\begin{array}{l}\text { Diagnostic samples may be collected during rehabilitative care and samples may be col- } \\
\text { lected for transfer to research facilities conducting research on contagious disease or public } \\
\text { health interests }\end{array}$ \\
\hline \multirow[t]{7}{*}{$\begin{array}{l}\text { Notifications and } \\
\text { administrative duties }\end{array}$} & $\begin{array}{l}\text { Suspected cases of poisoning, electrocution, gunshot injury, or other criminal activity must } \\
\text { be reported to the USFWS Law Enforcement Office listed on the permit }\end{array}$ \\
\hline & $\begin{array}{l}\text { Suspected cases of contagious disease or public health hazard should be reported to the } \\
\text { local or state public health officials }\end{array}$ \\
\hline & Permitted rehabilitators must maintain a working relationship with a licensed veterinarian \\
\hline & Complete and accurate records for all migratory birds received must be maintained \\
\hline & Must include date received, presenting complaint, disposition, and date of disposition \\
\hline & Records must be retained for 5 years \\
\hline & Annual report must be submitted to USFWS Regional Migratory Bird Permit Office \\
\hline
\end{tabular}

in educational activities using their birds. Education programs that utilized migratory birds are required to present a minimum of 12 presentations annually that include information about migratory bird ecology, biology, or conservation. Educational birds must be controlled at all times and not be allowed to have physical contact with the public. Additionally, birds should not be used in a manner which would imply personal ownership or use. The death or escape of a migratory bird covered by a Special Purpose (Education) permit must be reported within 48 hours.

Bald and Golden Eagle Protection Act: Title 50 CFR Part 22-The status as national symbol of the United States that was afforded the bald eagle in 1782 heralded a period of excessive hunting of this species until 1940 when Congress passed the Bald Eagle Protection Act. Killed for sport, display, and as a pest to farmers, the bald eagle was on the verge of extinction necessitating a comprehensive law that prevented the taking, possession, sale, purchase, barter, or offer therein "at any time or in any manner." In 1962, the same protection was applied to the golden eagle and the law was amended to the Bald and Golden Eagle Protection Act. As part of this amendment, a provision was made to grant permits to Native Americans to use eagles, eagle parts, and feathers, in religious ceremonies.

\section{US DEPARTMENT OF AGRICULTURE}

The USDA was founded in 1862, and today is charged with providing leadership on food, agriculture, natural resources, and related issues based on sound public policy, the best available science, and efficient management. It is composed of 33 agencies and offices, most of which are involved with food supply, food safety, nutrition and nutritional aid, animal health and welfare, and rural development. Within USDA resides the Animal and Plant Health Inspection Service.

\section{ANIMAL AND PLANT HEALTH INSPECTION SERVICE (APHIS)}

Established in 1972, APHIS is charged with promoting and facilitating US agricultural interests, regulating genetically modified organisms, administering the Animal Welfare Act, and managing wildlife damage and disease. Its mission of safeguarding US agriculture is mandated by the Animal Health Protection Act. APHIS is composed of six main program units: Animal Care, Biotechnology Regulatory Services, International Services and Trade Support Team, Plant Protection and Quarantine, Veterinary Services, and Wildlife Services.

APHIS-Animal Care (AC). APHIS-AC is responsible for leadership and enforcement of provisions of the Animal Welfare Act, determining standards of humane treatment of animals. It is the primary agency charged with inspection of facilities that conduct research with live vertebrate animals or display wild animals such as zoos, aquariums, and other facilities, as part of its mission to ensure animal welfare.

Animal Welfare Act: 7 USC 2131-2159-The Animal Welfare Act was first passed in 1966 as the Laboratory Animal Welfare Act, and it was amended and expanded to include other activities in 1970, 1976, 1985, and 1990, and USDA APHIS is charged with implementing this law. APHIS regulates the humane treatment of animals used in research, exhibition, or the wholesale pet trade through requirements for licensing and registration, maintenance of specific standards of animal care, and premise 
inspections. Through the Animal Welfare Act, APHIS also regulates the use of random source dogs and cats to prevent lost or stolen pets from being used in research, and prohibits animals used in fighting enterprises from being moved across state or international borders.

Animal Health Protection Act: 7 USC 83018322-This act was passed in 2002 and consolidated previous animal health legislation, and facilitates USDA APHIS's ability to respond to animal health threats such as pests or disease outbreaks. It authorizes animal quarantine provisions, delineates the accreditation program for veterinarians, and expands APHIS's role in planning and surveillance for bioterrorism-initiated outbreaks of animal disease.

APHIS-Veterinary Services (VS). APHIS-VS is a broad-reaching arm of APHIS, which is responsible for improving the health and well-being of animals while maintaining the safety of animals and animal products crossing US borders. VS staff are involved in control of animal pests and control and eradication programs for certain diseases, diagnostic testing, and compilation of information on animal health in the US. APHIS-VS is the primary agency responsible for animal disease outbreak control. This agency also deputizes a large portion of US licensed veterinarians through its voluntary accreditation program, enabling them to inspect animals and verify health status of animals prior to shipment, thus expanding surveillance activities against animal disease incursions into the US.

\section{APHIS-Wildlife Services (WS). APHIS-WS} includes several offices involved with the control of diseases in wild animals, including the Rabies Management Program. The goal of this program is to prevent the further spread of rabies in raccoons, coyotes, and gray foxes, thus reducing human and domestic animal exposure to this disease. This program partners with affected states to conduct vaccinations of free-ranging wild animals through use of oral vaccine bait. The APHIS-WS-National Wildlife Disease Program protects US agricultural interests through surveillance and control of other diseases spread by wild animals. These include several diseases carried by feral pigs (pseudorabies, brucellosis, swine fever, influenza, and anthrax among others), plus many others, including bovine tuberculosis, which may be spread by numerous wild mammal species, avian influenza viruses, which may be carried by waterfowl, and plague, which can be carried by chipmunks, ground squirrels, and prairie dogs. The APHIS-WS-National Wildlife
Research Center studies wildlife diseases, population management for overabundant species, invasive species, the effectiveness of wildlife damage management activities, control of agricultural pest species including those affecting forests, aquaculture and crops, plus conducts research on aviation safety involving wildlife interactions.

Shipping animals across state lines-States vary in what is required when moving animals between states. The regulations of the state receiving the animal controls what testing and other requirements must be met prior to moving the animal into the state. Contact the office of the State Veterinarian for information on regulations. These offices may be located at the following website: <http://www.usaha.org/Portals/6/ StateAnimalHealthOfficials.pdf $>$. APHIS maintains a website with links to each state's import requirements at $\langle$ http://www.aphis.usda.gov/import_export/animals/animal_import/animal_imports_states.shtml> but this information should be verified directly with each state, as changes may have occurred. Although APHIS does not have authority over shipment of birds between states, airlines typically require a health certificate, a United States Interstate and International Certificate of Health Examination for Small Animals (APHIS form 7001, <http://www.petrelocation. $\mathrm{com} / \mathrm{pdf} / \mathrm{APHIS7001}$.pdf $>$ ) completed by a USDA Accredited Veterinarian for animals being transported by air. Contact the relevant airline for more information on requirements regarding shipment of animals.

Movement of animals into Hawai'i is among the most stringent due to concerns for the large number of endemic, endangered species at risk from introduced diseases. For example, a bird shipped to Hawai'i may require pre-shipment testing for Avian Influenza and West Nile Virus, a Poultry and Bird Import Permit from the Livestock Disease Control Branch of the HI Dept. of Agriculture (808 837-8092), an Import Permit from the Plant Quarantine Branch of the HI Dept. of Agriculture (808 832-0566), an APHIS health certificate completed by a USDA Accredited Veterinarian, a 7 day pre-shipment quarantine in a mosquito-proof enclosure under the direct supervision (in clinic) of the veterinarian completing the health certificate, shipment in a mosquito-proof cage, and a 30 day post-shipment quarantine once in Honolulu.

Rehabilitators may wish to move migratory birds from Canada into the US instead of over-wintering them, due to birds receiving medical care in Canada and missing their migration window by the time they are ready for release. Information about transporting birds from Canada to the US may be found at 
<http://www.aphis.usda.gov/import_export/animals/ canada_bird.shtml>. At a minimum, birds will require an Application for Import or In Transit Permit (APHIS form VS 17-129) <http://www.aphis.usda. gov/import_export/animals/downloads/vs17_129. pdf $>$. Shipping a bird from Canada into the US does not require a health certificate, but does require the bird is examined by a USDA veterinarian at the port of entry, and entry is only allowed at specific points of land entry, airports, or ports. A list is available here: <http://www.aphis.usda.gov/import_export/animals/ animal_import/animal_imports_portvets.shtml>. An appointment must be made in advance for veterinary examination at the point of entry. Shipment of CITES listed species will likely require additional permits, and the destination state's importation rules must also be followed.

\section{DEPARTMENT OF HEALTH AND HUMAN SERVICES}

Created as the Department of Health, Education, and Welfare in 1953, the Department of Health and Human Services (HHS) directs programs that promote the general public well-being. The Office of Public Health and Science (PHS), under the HHS administration, serves to advise the HHS regarding matters pertaining to public health. The PHS implements many of the policies pertaining to public health, and oversight is administered by the US Surgeon General's Office. The Centers for Disease Control and Prevention (CDC) is also part of the PHS. Charged with providing leadership in the control and prevention of diseases, the CDC serves as the emergency response agency during public health emergencies. The CDC implements policies developed to prevent the introduction, transmission, and spread of communicable diseases from foreign countries. It also plays an important role in the regulation of animal importation, specifically regulating the importation of primates, psittacine birds, turtles, dogs, cats, and other wildlife that may be carriers of infectious disease. The CDC publishes the Compendium of Animal Rabies Prevention and Control, as revised annually by the National Association of State Public Health Veterinarians, in its Morbidity and Mortality Weekly Report. The Compendium strongly recommends that any person working with wildlife receive, at a minimum, rabies vaccination, appropriate training, and continuing education. No parenteral rabies vaccinations are approved for wildlife. Wild mammals exposed to a rabid animal should be euthanized immediately. Persons bitten by a wild mammal which might constitute rabies exposure should report the incident to their local public health department. Subsequent recommendations for management of the incident will be based on the species, exposure, and epidemiology of rabies in the region.

\section{US DEPARTMENT OF THE TREASURY}

The United States Department of the Treasury was established in 1789 and charged with oversight and management of the country's financial business. In general, the Treasury Department formulates and recommends economic, financial, tax and fiscal policies, serves as the financial agent for the US government, enforces laws pertaining to government finances, and manufactures US currency. The Financial Management Service of the US Department of the Treasury specifically provides financial and accounting services for federal agencies. Collection of taxes, loan payments, fines, and lease payments contribute to the more than $\$ 2.2$ trillion collected annually by the Service. The Financial Management Service is also responsible for collecting customs duties, including those imposed on the importation of regulated wildlife.

\section{US DEPARTMENT OF COMMERCE}

The US Department of Commerce was established in 1913 to encourage and promote international trade, economic growth, and advancement of technology in the United States. Housed within this office is the National Oceanic and Atmospheric Administration (NOAA) which Congress formed in 1970 to oversee environmental assessment, prediction, and stewardship. As part of this mission, NOAA is committed to protecting US ocean, coastal, and living marine resources while supporting sustainable economic development. The National Marine Fisheries Service (NMFS, also known as NOAA Fisheries) is the branch of NOAA that implements regulations overseeing marine fishery operations and governs the conservation and possession of marine mammals. In doing so, the NMFS enforces the ESA and Marine Mammal Protection Act. NMFS is charged with the conservation of depleted marine mammal populations, many of which are threatened or endangered, through the functions of the Office of Protected Resources. NMFS regulates marine mammals including cetaceans (dolphins, porpoises, whales), and most pinnipeds (seals and sea lions, but not walruses), plus sea turtles. Marine mammals under the jurisdiction of USFWS include sea and marine otters, manatees, walruses, and polar bears. Regional NMFS offices manage the Marine Mammal Stranding Network and the Sea Turtle Stranding and Salvage Network. Members of these networks possess Letters of Authorization from 
NMFS in order to work with NMFS regulated species. Information on acquiring a LOA to rehabilitate these species may be found at the Office of Protected Resources website at <http://www.nmfs.noaa.gov/pr/ permits/>.

\section{CONCLUSION}

The laws and regulations that protect wildlife are complex and the federal offices that implement these laws often appear to have overlapping mandates. Federal laws sometimes defer to state laws and regulations, many of which can be difficult to locate in available legislative documents. Laws pertaining to wildlife are subject to continual revision as the need for regulations evolves. The onus for maintaining a working understanding of pertinent laws falls to the wildlife care provider. Persons working with wildlife on a consistent basis are required to meet the standards set forth by federal, state, and local legislation. Being aware of laws regulating the management of wildlife and understanding where to locate relevant resources will enable veterinarians and rehabilitators to play an important part in the management of wild populations while avoiding potentially serious violations. Most individuals involved in wildlife rehabilitation work with a relatively small number of species or taxa; hence, focused attention can be placed on the regulations that apply to those species. Often, permits required for this work are managed by one federal and/or one state agency. Table 4 is a summary of agencies regulating specific taxa of wildlife. It is helpful to identify a point-of-contact person at the regulatory agencies you work with as these individuals can be extremely helpful in interpreting regulations and answering questions that arise regarding permits and wildlife laws.

\section{LITERATURE CITED}

Miller, E. A., editor. 2012. Minimum Standards for Wildlife Rehabilitation, 4th edition. National Wildlife Rehabilitators Association: St. Cloud, MN.

\section{RESOURCES}

Arent, L., and M. Martell. 1996. Care and Management of Captive Raptors. The Raptor Center at the University of Minnesota: St. Paul, MN.

CITES Species Database. Accessed November 2017. <http://www.cites.org/eng/resources/species. html>.

Compendium of Animal Rabies Prevention and Control. 2011. Accessed November 2017. <http:// www.cdc.gov/mmwr/pdf/rr/rr6006.pdf $>$

Endangered species list (by state): <http://www.fws. gov/endangered/>.

State fish and wildlife management offices: <http:// www.fws.gov/offices/statelinks.html>.

State veterinarian listings: <http://www.usaha.org/ Portals/6/StateAnimalHealthOfficials.pdf>

United States Code: <http://www.gpo. gov/fdsys/browse/collectionUScode. action? collectionCode $=$ USCODE $>$.

United States Code of Federal Regulations: <http:// www.gpo.gov/fdsys/browse/collectionCfr. action? collectionCode $=$ CFR $>$.

United States Government Manual 2011: <http://www.gpo.gov/fdsys/pkg/ GOVMAN-2011-10-05/pdf/ GOVMAN-2011-10-05.pdf>.

USFWS migratory bird permit regional offices: <http://www.fws.gov/migratorybirds/mbpermits/ Addresses.html>. (․ㅐㅇㅛ

Table 4. Summary of agencies regulating specific taxa of wildlife.

\begin{tabular}{|l|l|}
\hline \multicolumn{1}{|c|}{ SPECIES } & \multicolumn{1}{c|}{ REGULATORY AGENCY } \\
\hline Birds: Migratory & USFWS, state wildlife agency \\
\hline Birds: Non-migratory & State wildlife agency \\
\hline Mammals: Terrestrial & State wildlife agency \\
\hline $\begin{array}{l}\text { Marine mammals: Sea and marine } \\
\text { otters, manatees, walruses, polar bears }\end{array}$ & USFWS \\
\hline $\begin{array}{l}\text { Marine mammals: Seals, sea lions, ceta- } \\
\text { ceans (whales, dolphins, porpoise) }\end{array}$ & NMFS \\
\hline Reptiles: sea turtles & NMFS \\
\hline Reptiles: others & State wildlife agency \\
\hline
\end{tabular}

